Article

\title{
Regulating Desire: The Nature of Exhaustion in Ali Smith's Hotel World and Ewan Morrison's Tales from the Mall
}

\author{
Michael Paye \\ Department of English and Comparative Literary Studies, University of Warwick, Coventry CV4 7HS, UK; \\ michael.paye@warwick.ac.uk
}

Received: 12 September 2018; Accepted: 5 March 2019; Published: 8 March 2019

check for updates

\begin{abstract}
This article offers an ecocritical analysis of Ali Smith's Hotel World (2001) and Ewan Morrison's Tales from the Mall (2012). Through a combination of the world-ecology paradigm, feminist approaches, and queer theory, I argue that these texts connect normative desires to capitalism's "organization of nature." The opening section of the article links Nancy Fraser's work on social reproduction to Jason Moore's argument that nature, in world-ecological terms, provides the "free gifts" (of work, energy, and even care) necessary for capitalist productivity. Morrison's and Smith's texts register this dynamic, positioning hierarchy, sexism, and the uneven experience of neoliberal violence in relation to enclosure, attacks on women, and environmental destruction. I detail how Hotel World binds suburban ecology to normative regulation, while Tales from the Mall connects land clearance to the geographical organization of class inequality. I then contend that the psychological and physical exhaustion of women in both works can be understood in relation to capitalism's reduction of nature to an appropriable resource that provides comfort and pleasure for wealthy consumers. The article ends with an examination of how the texts reject liberal fantasies of benevolent capitalist globalization in the context of Scotland specifically, indicating the need for new narratives that challenge capitalism's ecological regime.
\end{abstract}

Keywords: Scottish literature; world-ecology; feminism; queer theory; environmental humanities

\section{Introduction}

Take a trip through the urban networks of late capitalism and you are certain to find malls and hotels in various forms. Malls are symbols of consumerism and capital influx, sites of waste and environmental destruction, as well as places of fun and frolics. The mall and its afterlife have acted as backdrops for explorers, as deadmalls.com attests, ${ }^{1}$ as well as numerous apocalyptic scenarios. In George A. Romero's Dawn of the Dead (1978) and Zack Snyder's same-titled remake (Dawn of the Dead 2004) survivors and zombies flock to the mall, registering both the consumerist impulse towards a familiar alienation, as well as, ironically, the community impulse of original mall designs, utopian spaces that "could literally lay a foundation for a better society" (Morrison 2012, p. 23). Similarly, hotels have played host to a variety of nightmare fantasies and manias, as in films like Alfred Hitchcock's Psycho (1960) and Stanley Kubrick's The Shining (1980), suggesting a continuity between malls and hotels as zones of survival-horror, where the mobile citizen encounters capitalism's psychotic underbelly and pays a bloody tax.

1 See www.youtube.com/deadmallsmedia. 
Ali Smith's Hotel World (2001) and Ewan Morrison's Tales from the Mall (2012) feature various incarnations of the undead, from actual ghosts to de-humanized labourers, evoking the alienation of capitalist consumerism. Hotel World follows five different narrator's journeys around the same unnamed UK locale, where a young hotel worker named Sara Wilby has recently died in an accident. Tales from the Mall is a collection of stories, visual imagery, interjections, and histories that chronicle the adventures of various mall goers, and is mainly set in Scotland. Both texts engage with the "vibrant consumer culture" and geographical unevenness precipitated by neoliberalism in Scotland and much of the North of England, as well as the pre-existing "debt, poverty, and inequality" exacerbated by Thatcherite reforms (Davidson 2010, pp. xi-xvi).

This article argues that Hotel World and Tales from the Mall interrogate how capitalism operates through class disparity, ecological plunder, heteronormativity, and mass consumerism. In Hotel World, the hotel brand promises the bourgeois consumer the experience of infinite surplus and comfort, naturalizing his/her superiority to, as well as difference from, service sector workers and most of humanity. In Tales from the Mall, the mall's production of scarcity and competition, and its commodification of sexuality, embraces the "liquidity" of contemporary neoliberalism, where social good is abandoned for "competitive selfishness" (Shapiro 2014, pp. 1265-67). The two texts emphasize the restrictions of the normative, the regulatory frame of suburbia, and the physical and mental exhaustion of numerous female characters, which are all, in part, materializations of capitalism's "naturalized inequalities" (Moore 2016, p. 82).

\section{Capitalist (Hetero)Normalization}

Thinking about capitalism, not just in relation to ecology, but as ecological, allows an understanding of the interconnections between environmental crises, growing class inequality, and violence against women. Nancy Fraser's work is instructive here. She demonstrates how women's primary role under capitalism, particularly since the nineteenth century, has centred on providing care and support outside of wage labour. This facet of social reproduction naturalizes capitalist relations from one generation to the next, on a continuum with the organization of "nature as a source of 'productive inputs'" (Fraser 2016, p. 101). Environmental historian Jason Moore goes even further, synthesizing social reproduction and environmental theory. He argues that capitalism is a "world-ecology," which converts "nature" and the potential energy it produces into an "ecological surplus" to fuel its accumulation regimes (Moore 2015, p. 95). Nature, in world-ecological terms, encompasses most of humanity and the natural world, consisting of common lands, women, water, and "inferior" races, which must be "put to work" cheaply for the greater (capitalist) good (Moore 2015, p. 213; Hartley 2016, p. 160). Moore traces the birth of "cheap nature" to the long-sixteenth century, when philosophers, imperialists, and governments solidified pre-existing hierarchies, positioning white, European, male "society" over "nature" (Moore 2015, pp. 193, 204; 2016, p. 89; Patel and Moore 2017, pp. 51-52). Nature and society thus represent "real abstractions," providing a vocabulary and way of seeing that excuses environmental violence and inequality in the name of accumulation (Patel and Moore 2017, p. 47).

To naturalize capitalism's hierarchies and obfuscate its violence, a succession of hegemonic states-Genoan, Dutch, British, then American-have developed a "cultural fix," which reproduces "durable class relations" outside of the labour process (Shapiro 2014, p. 1262). In the Keynesian period, the fix materialized in the post-war nuclear family's investment in civic responsibility, (white) middle-class growth, and religion, built upon a globalized network of cheap food, cheap oil, cheap labour, and the free work of housewives (Federici [1975] 2012; Shapiro 2014, pp. 1255-56; Moore 2015, pp. 249-61). Conterminously, the standardization of "heterosexual and homosexual subjects [...] as consuming subjects" in the twentieth century has enabled a wider normalization of capitalist relations by incorporating previously externalized sexualities and lifestyles, the "reification of sexual desire" itself (Floyd 2009, pp. 35-36). The pleasures of consumerism thus offer a false narrative of general equality for those who can afford to buy into it (Drucker 2015, pp. 18-24), but how much longer can this continue? Capitalism's cyclical crises have always emerged due to the tendency for 
the ecological surplus to decline, precipitated by increasing capitalization of nature, which makes appropriation too expensive (Moore 2015, pp. 91-109). Neoliberalism has been unable to develop a new, cheap nature regime, which has led to rising food and energy costs, ever-increasing levels of environmental destruction, as well as the widespread withdrawal of state assistance from care work essential to social reproduction. Many critics thus suggest that capitalism might be on the verge of an entirely new stage or possibly in its death throes (Fraser 2016, p. 113; Patel and Moore 2017, p. 129; Hartley 2016, p. 165).

These withdrawals, contradictions, and squeezes, though not traditionally considered "environmental" or "ecological," are central to debates taking place in the environmental humanities today. In a number of ecocritical publications and special issues, numerous literary critics have called for a world-ecological approach to world-literature, ${ }^{2}$ analysing texts from the perspective of capitalism's "transformation of the global environment" (Niblett 2012, p. 15; also Campbell 2016, p. 172). Such a transformation, as argued, includes patterns of sexual and social reproduction, what Kate Houlden (2017, p. 296) refers to as the "normative order." She writes that queer and world-literary theorists understand "narrative disjuncture and a literary politics of excess" as part of a formal critique of normative, capitalist society, a similar approach to literary world-ecology critics who interpret formal interruption and discontinuity as possible markers of ecological tensions or crises. We can therefore consider world-ecological, materialist queer, and feminist literary criticism as potentially complementary endeavours. Drawing on these schools, I will demonstrate that both Hotel World and Tales from the Mall undermine the logic of normativity, making visible the ecological, sexual, and class violence that consumerism relies upon.

I will begin this article by investigating how Smith's novel registers the regulatory mechanisms of suburban life, and then demonstrate how Morrison's work evokes a long-historical continuity between capitalism, land clearance, and the externalization of nature. I will then argue that women's subjective experiences of physical and mental exhaustion in Hotel World, and their reduction to objects for men's pleasure in Tales from the Mall, operates as a combined critique of capitalism's regime of cheap appropriation and devaluation of women. The final section of the article will outline how the texts evoke community malaise through an image of Scotland that is complicit in capital's ongoing ways of organizing nature. I will conclude by suggesting that these works speak to a literary recognition of the need for new narratives that challenge the inevitability of a capitalist future.

\section{Suburbs, Clearance, and Everyday Life}

Hotel World confronts capitalist unevenness through its character's distinct, often traumatic, experiences of neoliberalism (Levin 2013; Horgan 2016). Each chapter, except for the last one, narrates a particular woman's encounter with the same branch of Global Hotels, building a sense of connection through narrative in a world that, as the plot articulates, privileges bourgeois individualism. The novel encourages the reader to reflect upon temporality, naming each chapter after a tense: "past," "present historic," "future conditional," "perfect," "future in the past," and "present." Sara Wilby's accident remains a spectre throughout the novel, which ends with the revelation of mutual love between Sara and a watch repair worker she met prior to her death. Following Kaye Mitchell $(2013$, p. 72) argument that Smith's "general concern with non-normativity" indicates the possibilities of queer readings of her works, I argue that in Hotel World specifically, Smith foregrounds clock time to gesture towards a queer temporality that rejects a normative telos. The first chapter of Hotel World shows how sexual normativity and urban planning are combined within a normative, regulatory regime, which is an early indication of the novel's wider critique of capitalism's naturalized hierarchies.

2 By "world-literature," I do not mean a canon of postcolonial or globe-spanning texts, but a methodology that reads literature "through its mediation by and registration of the modern world-system" (WReC 2015, p. 9). 
The opening of Hotel World privileges a tension between the spiritual and material as Sara's decomposing body converses unwillingly with her ghost. The ghost has been roaming the hotel and streets surrounding it following Sara's fall down a dumb waiter shaft at the Global Hotel the previous summer. She rhapsodizes on the pleasures of sensation, wishing for "a stone in my shoe [...] that [...] jags into different parts of the sole and hurts just enough to be pleasure" (Smith [2001] 2002, p. 3), an urge to feel in a world that, as the novel later articulates, demands suppression of feeling outside of a heavily regulated network of consumption and exchange. The ghost envies the body's connection to the soil, vicariously declaring that "so many exciting things are happening to her now," as the "ticklish mouths of worms" (p. 9) bring the body into "the consolations of our place in the cycle of nascence and decay," a reminder that natural biophysical processes connect humans to the rest of nature in a non-instrumentalized form (Marland and Parham 2014, p. 7). Having no physicality with which to experience the material world, she flies above the concrete, taking in "flyovers groaning with the weight of their traffic," as well as "rubbished grass round the edges of stations; a dumped fridge; a burnt-out car; a piece of old furniture rotten with rain" (Smith [2001] 2002, p. 27). Through fields and housing estates, the ghost maps out an organized system of road networks, parks, and recreational facilities, but is unable to attach any emotional resonance to anything she sees.

Seeking connection and answers, Sara's ghost asks her body to give her more information about the fall that killed her. The term fall is given a double meaning as the body responds by explaining that "I fell in love" with a girl, having "expected all my life to fall for some boy, or some man or other, and I had been waiting and watching for him. Then one day my watch stopped" (p. 17). Upon entering a watch repair shop, Sara's heteronormative timeline is disrupted through a newfound lesbian desire kindled by the girl behind the counter, as the body recalls the revelatory experience of love: "I couldn't help it. I fell" (ibid.). This represents a realignment of her previous sense of progression, which had "internaliz[ed] the given cultural tempos and time lines" of heterosexual life. Queer theorist Elizabeth Freeman (2007, pp. 160-61) goes so far as to suggest that "even wristwatches are ways to inculcate [...] forms of temporal experience that seem natural to those whom they privilege." Sara marvels at the timepieces spread across the shop, "all of them stopped, with their hands pointing to different, possible, times of the day" (Smith [2001] 2002, p. 18), as the novel invokes the possibility of a new temporal-sexual progression that gravitates away from the heterosexual unit.

Sara must face the "shame" of feeling sexual desire outside of acceptable, heteronormative teleology (p. 22). Hotel World explores how her embarrassment comes in part from the regulatory spatial and ideological makeup of suburbia, which, as the novel shows, encourages normative behaviour based on the rejection of difference. After a three-hour walk following her sexual awakening, Sara decides to go to an outdoor pool. Her nervous euphoria evaporates as she notices people laughing in her direction, only to realize that they are mocking a woman who cannot fit comfortably into the women's cubicles and has started to change her clothes in full view of everyone:

A man called at her to cover herself up. I could hear female murmurs of agreement. No room for any water if she got into the pool, never mind room for the rest of us, the man next to me said; he was looking at my wet neck now, and I nodded and smiled because he was flirting with me, and slipped back into the water. (p. 21)

Leerom Medovoi (2013, p. 83), in his biopolitical analysis of environmental organization, notes that "the environment [can be] manipulated for its regularizing effects." In Hotel World, heteronormative expectations are upheld by small-town suburbia, materializing here through the changing rooms for slim swimmers and the flirtatious older man who feels entitled to judge female bodies. The narrative here infers how closely monitored the pool is, from the lifeguard enforcing acceptable behaviour, escorting the woman from the area, to the community's demeaning remarks towards her, eventually taking their leave with fond goodbyes "like we were old friends" (pp. 21-22). Sara evokes how such neighbourly bio-policing depends on the regulation of the corporeal and the mental, wondering "What the people at the outdoor pool, for example, if I were to take off all my clothes there in front of them right down to skin and thumping heart, would think" (Smith [2001] 2002, p. 23). Here, 
patriarchy and heteronormativity are naturalized within the dynamics of the suburbs, as multiple scales of regulation drive diverse subjects into hiding. Through small terraced houses bordered by "municipal grass" (p. 158) and "block[s] of tenement flats [...] that looked out on to the walls of other tenements" (pp. 82-83), neighbour is directed towards neighbour, a combined material and symbolic infrastructure that maintains the status quo through exclusion. Later chapters of the novel tie such normative behaviours and hierarchies more explicitly to regimes of appropriation, the cheapening of nature, and women's precarity, which I will explore in the next section.

Taking a more flippant approach to the everyday violences reproduced under capitalism, Morrison's Tales from the Mall revels in "the end of community" (Lyall 2016, p. 24). The text leaps between interviews, histories, short stories, mall maps, and images of signage and vandalism, embedding capitalist distraction in its very form, while explicitly critiquing how growing inequality and zero-hour contracts have led to a society built on "short-term personal goals without a broader collective narrative" (Morrison 2012, p. 10). In his opening salvo, an authorial overview of malls throughout history, Morrison recalls Scotland's troubled relationship with land, privatization, and proletarianization, as he builds a sense of continuity between clearance and global sweatshops:

The mollification of my country is an historic event, as important as the Jacobite Rebellion or the Highland Clearances. Those that do not believe this could do with asking themselves why most of the clothes they wear are manufactured in China and most of the culture they consume is made in America; why most of their population now works in retail. (pp. 8-9)

Through the spectre of the Highland Clearances, ${ }^{3}$ the text explicitly registers how Scotland's environment has operated for the benefit of British capitalism, linking a pivotal moment of cheap(ening) nature to contemporary supply chains of cheap work and labour. Clearances changed the ecological and social relations of the Highlands, as most humans in the clan, as well as the indigenous fauna, were swapped for "the dictatorship of the commodity" in the guise of sheep and deer farms (Moore 2016, p. 85). Morrison later outlines how the real abstractions of this "dictatorship" are buried within everyday language, which conceals unevenness within benevolent "nature." He traces the etymology of the word mall back to the word "pallemaille": "(a) a walkway bordered with trees (1702); (b) a grassy or paved pedestrian area between two roads or adjacent to a road; (c) an open area between buildings reserved for pedestrian usage" (pp. 109-10). Daniel Hartley (2016, p. 154) demonstrates that the term culture has "etymological roots in the soil," a definition originally tied to the cultivation of plant life that now encapsulates "a way of life or set of artistic activities" that bolster the hegemonic system. On a similar spectrum, the term mall charts an evolution from leisure to consumerism that is tied to manicured "nature." The "recurrence of rural motifs" (Morrison 2012, p. 112) in mall names further underlines how language entails affective imageries that negate the alienation explicit in mall shopping as well as the classist organization of urban and suburban ecologies. As Neil Davidson (2010, p. xi) writes, Scottish neoliberalism "condemned [working class citizens] to live on the peripheral estates," a rejection that "is exacerbated precisely by the contrast between their situation and that of the thriving majority." Malls are often located along high-speed motorways near "satellite housing schemes" that have no pedestrian access to the mall, or in more affluent zones so as to keep out undesirables (Morrison 2012, pp. 233-34), as developers take advantage of "lax zoning restrictions" and cheap real estate (p. 145). Tales from the Mall implicates mall development in the wider hierarchical values explicit in capitalism's organization of nature and class divisions. The text argues that mall names like "Bluewater, Braehead, Bull Ring, Cockhedge, [and] County Square" represent attempts to evoke a pastoral tranquillity that conceals how land is appropriated, recalling Raymond Williams (1973, p. 27) argument that literary pastoral represents a cultural tool for reproducing bourgeois ideology. Tales from the Mall's registration of the hegemonic power of rural aesthetics is thus connected to Britain's

3 The Highland Clearances were a series of population clearances across the late eighteenth-nineteenth centuries in Scotland that followed the disestablishment of the clan system (Davidson 2003). 
ecological and cultural regime over the longue-durée, as the mall uses imagery of pastoral nature to conceal the same logic of division and enclosure that once alienated clan members from their land.

As such, Morrison's and Smith's narratives demonstrate how urban and suburban organization regulate and reproduce normative attitudes, from heterosexual progression to modernization as a process of clearance and necessary exclusion. Furthermore, both texts register that capitalism's organization of everyday life relies upon naturalizing hierarchy and privilege, thereby normalizing capital's systemic violence. Class and gender divisions are thus embedded in the built environment, encouraging relations and attitudes that reproduce the status quo.

\section{Comfort, Competition, and Women on Demand}

The contradictions of capitalism run the whole way through supply chains to the commodity's final stage in the homes of consumers. The position of women has been central to concealing such frictions, their mobility and independence gradually restricted towards compulsory housewifery, "distort[ing]" their sexuality, emotions, and bodies for the benefit of whatever family unit enabled maximum production and, from the Keynesian period, consumption (Federici [1975] 2012, pp. 19-20; Floyd 2009, pp. 51, 55). This naturalized domesticity, by which women provide "affective and material labour" (Fraser 2016, p. 99), is essential to capital's ecological regime, part of the "free gifts" of cheap nature and work (Fraser 2016, p. 110; Moore 2016). In neoliberalism's individualist, desire economy, women remain consumers and commodities, facing new forms of violence in the afterlife of the welfare state. The tensions between the Keynesian cultural fix and the exhaustive tendencies of neoliberalism manifest in women's psychic displacement in Hotel World, as the novel ties traditional imaginaries of woman and nature to ongoing violence against humans and the environment.

In Hotel World, the group behind Global Hotels ensures that guests are insulated from their complicity in systemic violence, championing "site duplication" to instil a sense of "psychological security, nostalgia, and preserv[e] the climate of repeated-return in worldwide Global clientele" (Smith [2001] 2002, pp. 110-11). Outside of the comfort of the hotel, however, the immiserations of capitalism are explicit in the urban environment and the bodies within it. A homeless woman called Else symbolizes and recognizes the unevenness inherent to capitalist development. Throughout her chapter, the aptly titled "present historic" episode, Else notes the confluence of medieval and modern architectures across the city, but struggles to remember the number of days in a month or how to tell the time. She perceives her body as out of temporal alignment, imagining her lungs as "bad telephone lines, already outmoded anyway." She then loses herself in a complicated reverie, in which a repairman, upon arriving to connect up the lines, discovers that he is suddenly back in the fifteenth century (p. 40). Else understands that her physical and mental exhaustion is on a continuum with urban decay and historic erasure, and leans on the hotel wall for support:

Inside her, another wall holding her upright, it goes from her abdomen to her throat and it's made of phlegm, and occasionally, when she can't not cough, when she has to cough, can't stop herself, the wall crumbles. She imagines it breaking like rotten cement. But it has its uses. It keeps her upright. It's holding her up just as much as the hotel wall is. (ibid.)

Accustomed to being excluded, Else is surprised to be invited into the hotel by a sympathetic girl at the front desk named Lise, who organizes a free room for her. Once inside, Else is astounded by the amenities on display, but never feels at ease because she recognizes that such abundance depends on mass despair. Between bouts of coughing up phlegm, she considers the brightly coloured hotel shampoos with an embossed $G$ on the bottles, along with the "individually wrapped" toiletries. She recognizes that "Someone in a factory or workshop somewhere has wrapped up the soap in paper so that to use it you have to unwrap it like it's a gift" (Smith [2001] 2002, pp. 70-71). The "gift" is one of seeing no evil, as Else perceives how the $G$ ties into an overall experience of luxury that distances consumers from the labour behind the commodities they consume. She considers the taps in the bathroom similarly, marvelling at how water flows out of such "dazzling" appendages (p. 71), 
but becomes angry at herself: "They're just taps. They're just stupid fucking taps. All they can do is do what you make them do. They can't do anything else. Anything, Else" (p. 75). Else, "miserable" at the sight of such luxuries (p. 71), registers that exploitation in the factory is commensurate with the appropriation of free natures (like water) that flow out of faucets. Before exiting the hotel, she leaves the tap running, eventually causing the bathroom to flood, an act of unconscious defiance against middle-class presumptions of control and ownership. Her action results in damage to the carpet and "three separate complaints from other guests in the hotel between 8 p.m. and 9:30 p.m. concerning the lack of hot water" (Smith [2001] 2002, p. 105). The power vested in pipelines-be they for gas, oil, or water-is not simply a matter of gravity and engineering, therefore, but co-produces the bourgeois expectations of infinite resources and comfort. In a final signal of the link between on-demand service and precarity, and perhaps alluding to the tokenism of vandalism in the face of totality, a badly-paid chambermaid gets fired and fined for Else's act.

The ease with which women in the service industry can end up in Else's situation or the unfortunate chambermaid's is communicated through Lise's journey. Stricken with what appears to be Chronic Fatigue Syndrome, Lise is forced to resign from the hotel due to symptoms of pain, exhaustion, confusion, and periods of incapacitation that the novel explicitly links to her experience of life under neoliberalism. As she deals with hapless doctors and social welfare staff, her restless mind is assailed by numerous advertisements from "years ago" (p. 82). Though no date is provided, the advertisements recall imaginaries of natural female domesticity that were central to the Keynesian cultural fix, featuring joyful, white, middle-class women cooking with corn oil, eating hearty breakfasts, and washing happy children. Through the three advertisements, Smith presents three idealized images of consumerist femininity: the housewife, "the successful and socially-upwardly-mobile woman" (p. 85), and the mother. Anchoring herself to this imaginary, Lise recalls an advertisement for Mazola corn oil in which the "hands of a lady" prove how little residue Mazola leaves on cooked chips (p. 82). She similarly feels "comforted" by her memory of Country Store and Matey Bubble Bath ads (p. 98), the former reproducing a pastoralist image of hearty nature that provides a young woman with the "good things" (p. 85), and the latter promising a clean bathtub and contented children to the pleasure of the "joyful mother" onscreen (p. 98). The afterlife of the twentieth-century cultural fix, so dependent on the guarantee of infinite nature for appropriation and the free work of housewives, gives Lise respite in an era that villainizes those who cannot contribute to value. Conversely, her description of her own illness captures the ideology of no alternative in neoliberalism, a terminal "Unwell [...] of no apparent narrative" (p. 84) that has replaced the teleology of middle-class benevolence and happy domesticity as seen on TV. Echoing Morrison here, Smith exposes how branding and advertising offset exhaustion onto the most vulnerable, on a continuum with the $G$ on the shampoo bottle, normalizing a distracting consumerism that contrasts sharply with the possible futures that Sara's desire portends. There is, in fact, an implicit violence in these advertisements, since they deny suburbia's dependence on cheap/free work and monocropping while making the exploitation of corn oil workers and factory labourers invisible. The novel here reflects how the spectacle of joyous suburban and pastoral life thus provided distraction in the post-war era even before the overt attacks on labour and social reproduction that have accompanied neoliberalization (Fraser 2016). The fragile bodies of Sara, Lise, and Else are therefore shown to be on a continuum with externalized nature across the longue-durée, as the pressure to maintain social reproduction in an era that lacks cheap energy, cheap water, and cheap food manifests in the women's somatic and psychological exhaustion (Moore 2015, p. 235).

Following the narratives of Sara's ghost, Else's brief hotel experience, and Lise's illness, the novel moves on to Penny, a journalist from an elite background who embraces the on-demand experiences of neoliberalism. She indulges in suburban voyeurism by following Else around housing estates, but her purview, though initially shaken by what she sees, remains unchanged. Upon returning to her room, Penny orders a club sandwich and hot chocolate from reception, decrypts a porn channel that she leaves on while writing up a supercilious review, and cancels a cheque made out to Else, "pleased with herself first for the initial extravagance of her act, and next for being able to, crucially 
being sensible enough to, put a stop to it" (Smith [2001] 2002, p. 178). Unlike the previous era's cultural fix, where the naturalization of woman-as-housewife justified consumption in relation to health and family wellbeing as advertised, Penny's attitude reflects neoliberalism's normalization of a growing underclass. She abstracts impoverishment from its material history, evoking an ideal of timeless poverty, and thinks, "If you were poor, you were poor. [...] It was no accident that the words poor and pure were so alike" (ibid.). Strikingly, the novel links this attitude to Penny's wider understanding of her relationship to humans and non-humans. While watching television, she comes across a programme with a medium who claims to be in contact with a family member of someone in the audience. This causes Penny to consider "All the people who have ever died [...] soundlessly shouting [...] We're not dead! Don't call us dead!" (pp. 127-28). She then considers the much longer history of non-human life on earth, imagining dinosaurs and "airborne germs" who equally proclaim, "Don't call us dead!" (p. 129). Instead of an epiphany or engagement with the human and extra-human across time and space, which this thought process seems to engage-even structurally, the exhaustive description of plants, animals, and other life-forms lasts for over two pages-Penny distracts herself by clicking the keyboard to drown out the "infernal noise" (ibid.). Here, she rejects any form of temporality that might challenge her privileged sense of the present and blocks out empathy with other beings, living or dead. From following Else through the estates to momentarily assisting Sara's sister-mainly out of boredom - with the removal of the wall panel that conceals the dumb-waiter shaft, Penny's "openness to experience" precludes sustained interest in challenging the status quo (p. 164), reflecting the "apathetic individualism" of neoliberal subjectivity (Shapiro 2014, p. 1265). Her indifference to complex connections contrasts with Else's registration of how cheap nature and cheap labour are precisely what enable bourgeois comfort. The chapter ends with Penny finishing up her review, an advertisement that promises "the comfort of flawless staff attention [and] an effortless visit" to the prospective client (Smith [2001] 2002, p. 181). She thereby contributes to a larger culture of abstraction, making exploitation and appropriation invisible while normalizing hierarchy and elite entitlement.

Like in Hotel World, Tales from the Mall registers how the strain of temporal instability, exploitation, and competition is etched onto women in the service industry for the sake of middle-class comfort. One of the longest tales follows a Tesco Express worker, who notices that she is "forgettin the words these days. [...] The brain's mince" (Morrison 2012, p. 158), a result of the long-term effects of listening to the same jokes, watching the same television programmes, and seeing the same kinds of customers. The worker calls this phenomenon "dejas" (ibid.), a near permanent state of déjà vu that makes "zombies" of young women worn down by repetition and poverty (p. 160). Their psychic rift is the trade-off for the experience of shoppers for whom amusement and spectacle are organizing principles that, as Shapiro (Shapiro 2014, pp. 1265-66) writes, distract people from "the spirit of concentration" that might allow a more cogent opposition to capitalist alienation. Alliance is discouraged as malls appeal to "singles [who] are the largest growth market segment" (Morrison 2012, p. 236). This process not only follows the logic of capital, but is explicitly designed for heterosexual empowerment (Ahmed 2013, p. 163). Morrison's tale of a pickup artist training seminar, fittingly entitled "Top Man," critiques the violence of masculine entitlement by articulating how competition, consumer choice, and desire reduce women's bodies to a dualist fusion of appropriable nature and exchangeable commodity.

The pickup artist, or PUA, is the sexual configuration par excellence of contemporary capitalism. As Rachel O'Neill (2015) writes, PUAs teach men how to "manage," coordinate, and organize sexual experiences through expensive training courses and manuals detailing the best methods for seducing women, "consistent with broader reconfigurations of intimacy and subjectivity taking place within neoliberal capitalism." Inherently chauvinist, the PUA enacts "authentic, natural, core maleness-always construed as heterosexual," a man who has the right to the best resources (i.e., natures), including women (Cosma and Gurevich 2018, p. 95). In “Top Man," a PUA named Stealth trains young men in seduction techniques at the mall. Unlike the hotel and television advertisements, which require the ideal of infinite surplus natures for comfort, the shopping mall "manufactur[es] 
a scarcity" of elite brands upon release to enable "Peak Experience," the euphoria of assertion and "identity affirming action" through purchase (Morrison 2012, pp. 120, 223). Stealth engages with this neoliberal imaginary, positioning women as commodities of varying values and scarcities, and states that every man can engage "subliminal trust triggers" for "accelerated intimacy" with any woman (p. 96). This methodology for sexual success brings the sexual objectification of the female body and the "natural" drives of men to pursue the most attractive mate into a nexus between commodity exchange and desire, while simultaneously biologizing "woman" as heterosexual and inferior to man.

Stealth encourages his charges to build up their confidence through lower-ranked women before "going for that ten-girl" (p. 89), reproducing the "ego insecurity" of consumer culture to sell tickets to his seminars and grant men a sense of natural privilege (pp. 226-27). However, the actual training session articulates the fragility of masculinism. One of the men, Dave, takes shelter in a Starbucks with a passing back-packer named Daisy, confessing that he is trying to hide from the PUA group having been signed up to it by his friends. Daisy finds the scenario hilarious, and upon seeing the group watching them, kisses Dave, then charges towards the PUAs and screams "FUCK OFF," turning their performance on its head as they "finally [...] slop[e] away" (p. 106). Though the PUA revels in making the abstract real, turning the "social" space of the mall into a place to engage "primordial [...] cave man stuff" (p. 96), as Stealth puts it, the men are unable to exert the kind of control he promises. With sexual desire reified in a series of targets, techniques, and ratings, the PUA, despite his fantasy of pre-modern, masculine dominance, demonstrates that heteronormativity is not natural, but enacted. Though Stealth claims to have "picked up most of my top three hundred chicks in malls" (p. 89), Daisy rejects her reduction to cheap, on-demand pleasure by playing a role outside of PUA reckoning and instead engages with the performative possibilities enabled by the mall space.

Ultimately, both texts register that neoliberalism does not incorporate a progressive politics for all, but repackages the historical debasement of nature and women for the pleasure of elite consumers. Previous cultural fixes not only fail to compensate for neoliberalism, but, in their afterlife, make the continuing brutality of appropriation, exploitation, and dehumanization even more explicit. In all this, the role of Scotland, as both victim and perpetrator of interrelated world-ecological, regional, and local violence, arises frequently in Tales from the Mall and is invoked strategically in Hotel World. The final section of this article thus moves to Smith and Morrison's respective critiques of Scotland's imbrication in regimes of xenophobia, appropriation, and (neo)colonialism.

\section{Scotland, the World-Ecology, and Consumerism}

In Hotel World, Lise and Else find themselves in particularly precarious positions due to illness and homelessness respectively. Though Scotland is rarely invoked in the novel, its landscape and agrarian histories appear sporadically in moments of extreme trauma for both women. In one instance, Else recalls having sex as a young teenager with a forty-year-old man while her mother is showering upstairs. His furrowed brow makes her think of Scottish run-rig farming (Smith [2001] 2002, p. 60), a communal, cyclical mode of agriculture disestablished by the Highland Clearances. Though this could be dismissed as the random thoughts of a child coping with pain and trauma, in a similarly visceral recollection, during one of her "pierced" dreams, Lise finds herself "on the back of a black and white pig." Disoriented and afraid, she is a helpless passenger as "the pig is galloping, almost flying, at a dangerous speed over a landscape, fluid beneath her, that looks like Wales or the Scottish borders. When she wakes up from this dream she will be exhausted and panicked" (p. 107). Carla Sassi (2009, pp. 146-47) points out that, for twentieth-century authors, the border became symptomatic of tensions "between a dominant culture and a resistant one," as writers of the Scottish Renaissance used a sense of "downtrodden and marginalized Scottishness" to seek new creative and aesthetic vistas. In Smith's twenty-first century novel, instead of valorising a pre- (or post-) border world, the symbolic violation of commoning practices and borders implies the exhaustion of the traditional imagery of Scottish clanship, creativity, and even pre-capitalist stability. This pre-union base, whether real or imagined, 
cannot compensate for the long-historical and contemporary violence of capitalism, emerging here in an unheimlich dreamscape.

More generally, Smith rejects the easy layover between liberal democracy and "egalitarianism" with which Scotland is often associated (see Lyall 2016, p. 2), as the novel links global regimes of appropriation to Scotland's troubled history of capitalist reform. While running through the numerous things people have said to her while homeless, Else recalls a female police officer who recommends free counselling for "poor" people. The word poor reminds her of a school lesson on Scottish philanthropist Robert Owen, "who built the workers in his factory a church and a school and a hospital, and didn't employ the very youngest of their children until they were a bit older than the age that other men who weren't philanthropists employed children at. New Lanark was the name of his mills" (Smith [2001] 2002, p. 44). As Alissa Karl (2014, p. 79) suggests, Smith invokes Scotland here without explicitly mentioning the country to "underscore the sameness imposed by transnational corporations," while still indicating the "distinct regional and national histories" that continue to exist despite this. However, this interpretation can be pushed further. Hotel World registers a capitalist continuum between the reformist inclination of Owen's work and neoliberal adjustments, as immediately following this memory, a newspaper headline wrapped around Else's feet catches her attention: "BRITAIN MASSIVELY MORE UNEQUAL THAN 20 YEARS AGO. ONE IN FIVE PEOPLE LIVES BELOW BREADLINE" (Smith [2001] 2002, p. 45). The novel's juxtaposition of liberal reform and neoliberal impoverishment suggests a critique of capitalist "improvements" over the longue-durée. Furthermore, New Lanark depended on networks of exploitation and slavery, as Owen's organization of social and labour reproduction, though granting better conditions and protections for workers and their families, operated through "the inequalities and exploitations of capitalist enterprise," from the cotton plantation to the storefront (see Morris 2018, p. 111). Hotel World thus expresses how the "law of cheap nature" materializes through capitalism's combined and uneven development, registering how the improvement of the standard of living for humans in core zones depends upon violent appropriation regimes in global peripheries (Moore 2015, p. 290).

Championing a cultural fix beyond the British Empire's colonial and class hierarchies, the American hegemon exported interconnected ideals of capitalism, democracy, class mobility, and rising living standards through its post-war globalization priorities. Tales from the Mall invokes and ironizes this fantasy of freedom through consumption, articulating the lived experience of inequality that the US dream both denied and relied upon. To finish this article, I want to briefly focus on an episode of Morrison's text set in a peripheral region of Scotland that emphasizes globalization's unevenness. In the tale in question, a character named Joe, who works for an American corporation, visits the Scottish town in which he spent his childhood years. Joe has found stability in a relationship with an American man, Ted, who, upon learning of Joe's plan to visit the town, is concerned for his safety. As a boy, Joe suffered a vicious, homophobic assault from local children, a manifestation of the community's ire against American elites like his father, who "str[ode] around town, flashing his cash" (Morrison 2012, p. 65). Joe, now an elite himself, drives from his hotel towards the town and finds himself unable to separate the Scottish scenery from its scenic selling points, as "Mountains, castles and villages speed by as if they're an advert for the car itself" (p. 61). Upon arrival, he finds the old department stores and local butchers closed, the harbour deserted, and a Job Centre standing where a nightclub used to be. More investigation reveals empty, "luxury" accommodation next to a deserted carpark, not far from "the housing scheme" (p. 66). He crosses the fields towards the airport bunker where the assault occurred, only to find that everything has been replaced by a mall.

As Joe watches multiple generations enjoying their mall experience, he recalls a comment from a colleague on capital's cynical embrace of equality: “Our company, Stefan used to say, has opened its doors to all races and classes. When we are in every country in the world, and everyone gets to share in our discounts, then everyone will be equal and there will be peace" (p. 70). Stefan's absurd invocation of post-racial, free-market liberalism articulates how the afterlife of America's cultural fix depends on a homogenizing ethos that imagines diverse Europeans and Americans 
as consumer-citizens. And yet, the tensions precipitated by capitalist unevenness, local erasure, and desire manifest in the children's violent hatred of Joe and the town's xenophobic attitude towards his family. As he wryly notes, this "small, insular community [...], fearful of invaders" still imitated American habits and listened to American music but would mutter "Yanks go home" whenever his family was within earshot (pp. 64-65). Decades later, Joe is now a witness to the lure of the mall, where identity is sought, not through local factions, but recognizable brands. While Tales from the Mall as a collection demonstrates that regional polarities, racism, and sexism still exist, Stefan's consumerist utopia comes to pass because of people's unwillingness to organize against capitalist "development," distracted by the cosmetic fix of a new mall. Denied both closure and revenge by the mall, "Once again [Joe] is running" by the end of the tale (p. 71), perhaps trying to escape a pigeonhole built on consumerism and capitalist diversity that denies violent histories of land appropriation, community erasure, and normative regulation.

\section{Conclusions: Moving Beyond Neoliberalism}

Tales from the Mall and Hotel World register the scalar interrelations between world-ecological configurations and urban/suburban organization, from the "microsocial forms of normativity and discipline" that mark the body at the local mall, neighbourhood pool, and housing estate, to the global appropriation regimes that, in the long term, exhaust the conditions necessary for capitalist reproduction (Floyd 2009, p. 35; Moore 2015, p. 123). Nonetheless, hope is offered late in Hotel World (Smith [2001] 2002, p. 236), as the watch repair worker, who has fallen for Sara but has not yet learned of her death, fixes her watch so that it is "keeping good time," and plans to tell her that there is "no charge. It's on me." This promise of good time over the stressed temporalities of contemporary capital, and the rejection of exchange value for love, gestures towards a different future to the on-demand desire of hotel experience, as springtime imagery at the end of the novel invokes the possibility of new human and extra-human growth.

Conversely, oppositional gestures and petty acts of vandalism in Tales from the Mall show little evidence of a concerted politics. The text ends with consumerism's victory over subjective happiness, as a broke realtor rehearses his script to sell luxury apartments overlooking a new mall development: "A space open to possibility. Yes, finally, you are here, you are here" (Morrison 2012, p. 336). Although tempting to read this moment in line with the multiple defeats experienced at the mall by numerous characters, this ending might unconsciously leave space for a different spatiotemporal configuration: If the "here" that is "open to possibility" seems to be one of capitalist exchange, perhaps an unspoken "there" articulates the desire for a more radical sense of community beyond the mallscape.

As such, by comparing Tales from the Mall and Hotel World, an emancipatory structure of feeling emerges in opposition to dominant individualism. The texts indicate that environmental violence is not limited to atmospheric toxicity, extractivism, and pollution, but experienced in the normalization of masculinist and capitalist hierarchies in everyday life. Far from no alternative, a world-ecological reading attuned to queer and feminist theories demonstrates how both texts reveal the gaps in capitalism's ways of organizing and externalizing nature, signalling that a politics that refuses exploitation in favour of something new is just under the surface.

Funding: This research is funded by a Marie Skłodowska-Curie WIRL-COFUND Postdoctoral Fellowship.

Acknowledgments: My thanks to the special issue editors and three anonymous peer reviewers for their insightful comments and helpful editorial direction.

Conflicts of Interest: The author declares no conflict of interest.

\section{References}

Ahmed, Sara. 2013. The Cultural Politics of Emotion, 2nd ed.Edinburgh: Edinburgh University Press.

Campbell, Chris. 2016. Glancing backwards: George Lamming, John Cowper Powys and vexed visions of labour in the capitalist world-ecology. Green Letters 20: 170-82. [CrossRef] 
Cosma, Stephanie, and Maria Gurevich. 2018. (Re)producing the "natural man" in men's online advice media: Achieving masculinity through embodied and mental mastery. Psychology E Sexuality 9: 86-97. [CrossRef]

Davidson, Neil. 2003. Discovering the Scottish Revolution: 1692-1746. London: Pluto Press.

Davidson, Neil. 2010. What was neoliberalism. In Neoliberal Scotland: Class and Society in a Stateless Nation. Edited by Patricia McCafferty, David Miller and Neil Davidson. Newcastle upon Tyne: Cambridge Scholars Publishing, pp. 1-92.

Dawn of the Dead. 1978. Directed by George A. Romero. Laurel: United Film Distribution Company.

Dawn of the Dead. 2004. Directed by Zack Snyder. Universal City: Universal Pictures.

Drucker, Peter. 2015. Warped: Gay Normality and Queer Anticapitalism. Chicago: Haymarket Books.

Federici, Sylvia. 2012. Wages against housework. In Revolution at Point Zero: Housework, Reproduction, and Feminist Struggle. Oakland: PM Press, pp. 15-22. First published 1975.

Floyd, Kevin. 2009. The Reification of Desire: Toward a Queer Marxism. Minneapolis: University of Minnesota Press. Fraser, Nancy. 2016. Contradictions of capitalism and care. New Left Review 100: 99-117.

Freeman, Elizabeth. 2007. Introduction to Queer Temporalities. GLQ 13: 159-76. [CrossRef]

Hartley, Daniel. 2016. Anthropocene, Capitalocene, and the problem of culture. In Anthropocene or Capitalocene? Nature, History, and the Crisis of Capitalism. Edited by Jason W. Moore. Oakland: PM Press, pp. 154-65.

Horgan, Mary. 2016. About change: Ali Smith's numismatic modernism. Contemporary Women's Writing 10: 155-74. [CrossRef]

Houlden, Kate. 2017. Queering the world or worlding the queer? New readings of Anna Kavan's Who Are You? Women: A Cultural Review 28: 295-311. [CrossRef]

Karl, Alissa. 2014. Things break apart: James Kelman, Ali Smith, and the neoliberal novel. In Reading Capitalist Realism. Edited by Alison Shonkwiler and Leigh Claire La Berge. Iowa: University of Iowa Press, pp. 64-88.

Levin, Stephen. 2013. Narrating remainders: Spectral presences in Ali Smith's fictions. In Ali Smith: Contemporary Critical Perspectives. Edited by Monica Germana and Emily Horton. London: Bloomsbury, pp. 35-47.

Lyall, Scott. 2016. 'Tenshillingland': Community and commerce, myth and madness in the modern Scottish novel. In Community in Modern Scottish Literature. Leiden: Brill, pp. 1-24.

Marland, Pippa, and John Parham. 2014. Remaindering: The material ecology of junk and composting. Green Letters 18: 1-8. [CrossRef]

Medovoi, Leerom. 2013. The biopolitical unconscious: Toward an eco-Marxist literary theory. In Literary Materialisms. Edited by Mathias Nilges and Emilio Sauri. New York: Palgrave Macmillan, pp. 79-92.

Mitchell, Kaye. 2013. Queer metamorphoses: Girl meets boy and the futures of queer fiction. In Ali Smith: Contemporary Critical Perspectives. Edited by Monica Germana and Emily Horton. London: Bloomsbury, pp. 61-74.

Moore, Jason. 2015. Capitalism in the Web of Life: Ecology and the Accumulation of Capital. London: Verso.

Moore, Jason. 2016. The rise of cheap nature. In Anthropocene or Capitalocene? Nature, History, and the Crisis of Capitalism. Edited by Jason W. Moore. Oakland: PM Press, pp. 78-115.

Morris, Michael. 2018. The problem of slavery in the age of improvement: David Dale, Robert Owen and New Lanark cotton. In Cultures of Improvement in Scottish Romanticism, 1707-1840. Edited by Alex Benchimol and Gerard Lee McKeever. London: Routledge, pp. 111-31.

Morrison, Ewan. 2012. Tales from the Mall. Glasgow: Cargo Publishing.

Niblett, Michael. 2012. World-economy, world-ecology, world literature. Green Letters 16: 15-30. [CrossRef]

O'Neill, Rachel. 2015. The work of seduction: Intimacy and subjectivity in the London "seduction community". Sociological Research Online. 20.4. Published electronically Nov. 2015. Available online: www.socresonline. org.uk/20/4/5.html (accessed on 8 April 2018).

Patel, Raj, and Jason Moore. 2017. A History of the World in Seven Cheap Things: A Guide to Capitalism, Nature, and the Future of the Planet. Oakland: California University Press.

Psycho. 1960. Directed by Alfred Hitchcock. Hollywood: Paramount Pictures.

Sassi, Carla. 2009. The (b)order in modern Scottish literature. In The Edinburgh Companion to Twentieth-Century Scottish Literature. Edited by Ian Brown and Alan Riach. Edinburgh: Edinburgh University Press, pp. 145-55.

Shapiro, Stephen. 2014. From capitalist to communist abstraction: The Pale King's cultural fix. Textual Practice 28: 1249-71. [CrossRef]

Smith, Ali. 2002. Hotel World. London: Penguin Books. First published 2001.

The Shining. 1980. Directed by Stanley Kubrick. Burbank: Warner Bros. 
Williams, Raymond. 1973. The Country and the City. New York: Oxford University Press.

WReC (Warwick Research Collective). 2015. Combined and Uneven Development: Towards a New Theory of World-Literature. Liverpool: Liverpool University Press. (CC BY) license (http://creativecommons.org/licenses/by/4.0/). 